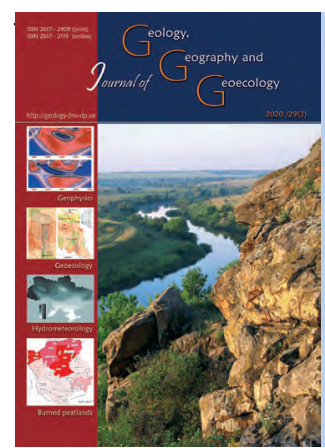

Journal of Geology,

ISSN 2617-2909 (print)

Geography and

Geoecology

ISSN 2617-2119 (online)

Anastasia A. Klieshch, Nadiya V. Maksymenko

Journal home page: geology-dnu-dp.ua

Journ.Geol.Geograph.

Geology,

29(3), 539-549.

doi: $10.15421 / 112049$

\title{
Positional-dynamic territorial structure of the urban landscape
}

\author{
Anastasia A. Klieshch, Nadiya V. Maksymenko \\ V. N. Karazin Kharkiv National University, Kharkiv,Ukraine,nadezdav08@gmail.ua
}

Received: 09.05.2020

Received in revised form: 19.05 .2020

Accepted: 25.05.2020 \begin{abstract}
of nature in environmental management. Methods: a positional-dynamic structure of urban landscape was selected by compiling and analyzing cartographic works of landscape strips, tiers and districts. Territorial configuration of different types of landscape strips were identified and established based on the classical scheme of landscape locations typology by water-geochemical regime proposed by B. Polynov and supplemented by M. Glazovska, which includes 9 main types. Technically, synthesis of parameters combinations and determination of the territories affiliation to certain types of landscape strips was carried out using spatial analysis tools (in particular, reclassification and raster calculator) of initial data on morphometric relief parameters in ArcGIS. Results. A set of qualitative parameters is proposed, based on the characteristics of each type of landscape strips by which they can be identified.Composition and territorial configuration of positional-dynamic landscape strips of the urban landscape are established as a result of systematization and processing of geodata parametric features of the water-geochemical regime. Cartographic models of the positional-dynamic structure of Kharkiv landscapes have been developed, including 13 types of landscape strips with individual features united in 5 groups by types of lateral migration of substances due to the peculiarities of their positionality (common position in relation to frame lines of flow directions) and factors of relief morphology similarity, nature of income and intensity of substances transfer. The identified mode types and the nature of the spatial distribution of the corresponding landscape strips have been described in detail. Conclusions. Cartographic models of the positional-dynamic territorial structure of Kharkiv, developed during the inventory stage of landscape-ecological planning, make it possible to choose areas of balanced nature management of a particular area.
\end{abstract}

Keywords: positional-dynamic structure, landscape-ecological planning, nature management, environmental management, cartographic model, urban landscape

\section{Позиційно-динамічна територіальна структура міського ландшафту}

\section{А. А. Клєщ, Н. В. Максименко}

Харківський національний університет імені В. Н. Каразіна, Харків, Україна, nadezdav08@gmail.ua

Анотація. Використання знань позиційно-динамічного устрою ландшафтів в процесі їх територіального планування дало поштовх до їх включення до складу робіт із ландшафтно-екологічного планування територій міських ландшафтів, що мають власну специфіку як об'єкти інвайронментального менеджменту. Мета - створення картографічних моделей позиційнодинамічної територіальної структури ландшафту м. Харків для забезпечення збалансованого природокористування в інвайронментальному менеджменті. Виділення позиційно-динамічної структури міського ландшафту відбувалось шляхом укладання та аналізу картографічних творів ландшафтних смуг, ярусів та районів. Ідентифікація та встановлення територіальної конфігурації різних типів ландшафтних смуг спирались на класичну схему типології місцеположень ландшафту за водно-геохімічним режимом запропоновану Б. Полиновим та доповнену М. Глазовською, що включає 9 основних типів. Технічно операція синтезу комбінацій параметрів та визначення приналежності територій певним типам ландшафтних смуг здійснювалась за допомогою інструментів просторового аналізу (зокрема, рекласифікації та калькулятора растрів) вихідних даних щодо морфометричних параметрів рельєфу у середовищі ArcGIS. На основі характерних ознак кожного 3 типів ландшафтних смуг запропонована сукупність якісних параметрів, за якими вони можуть бути ідентифіковані. В результаті систематизації та обробки геоданих параметричних ознак водно-геохімічного режиму встановлено склад та територіальну конфігурацію позиційно-динамічних ландшафтних смуг міського ландшафту. Розроблено картографічні моделі позиційнодинамічної структури ландшафтів м. Харків, яка включає 13 видів ландшафтних смуг із індивідуальними рисами, що об'єднані у 5 груп за типами режиму латеральної міграції речовини зумовленими особливостями їх позиційності (спільного положення по 
відношенню до каркасних ліній зміни напрямків потоків) та факторами подібності морфології рельєфу, характеру надходження та інтенсивності переносу речовин. Зроблено детальну характеристику виявлених типів режимів та характеру просторового поширення відповідних ним різновидів ландшафтних смуг. Картографічні моделі позиційно-динамічної територіальної структури м. Харків, розроблені під час реалізації інвентаризаційного етапу ландшафтно-екологічного планування дають можливість обрати напрями збалансованого природокористування в інвайронментальному менеджменті конкретної території.

Ключові слова: позичійно-динамічна структура, ландшафтно-екологічне планування, природокористування, інвайронментальний менеджмент, картографічна модель, міський ландиафт

Introduction. Theoretical foundations of the positional-dynamic structure of the landscape were first formulated by a team of Ukrainian scientists for the needs of rational agriculture (Shvebs \& Shyshchenko, 1990), (Hrodzynskyi \& Shyshchenko, 1993). Subsequently, the main provisions generalized and involved in the study of territorial configurations of landscapes in the monograph (Hrodzynskyi, 2005), were found in the study of self-organization of fluvial relief in the monograph (Kostrikov \& Chervanyov, 2010). Some fundamental provisions were included in the professional educational publications of the higher school of Ukraine (Hrodzynskyi, 2014). There is also experience in establishing regional aspects and local features of the positional-dynamic structure of landscapes in different regions of Ukraine, using GIS (Kostrikov \& Maksymenko, 2010; Karpets, 2015; Vlasova, 2013; Udovychenko, 2016a; Udovychenko, 2016b).

In general, the knowledge of landscapes' positional-dynamic structure in the process of their spatial planning gave an impetus to their inclusion in the work on landscape and ecological planning of urban landscapes. The last ones have their own specifics as objects of environmental management (Maksymenko \& Klieshch, 2017; Maksymenko 2018). During the inventory stage of landscapeecological planning of city landscapes it is difficult to isolate natural or anthropogenic factors in territory formation. Quite often the existing appearance of the day surface of certain areas looks quite natural, but it is the result of long-term transformation (backfilling of gorges, ravines, hills leveling, cutting of slopes, etc.). At the same time, during the construction, reconstruction or redevelopment of the territory it is necessary to have reliable information about the positional and dynamic structure of the landscape. As we have noted earlier (Klieshch, Maksymenko, \& Ponomarenko, 2017), there is a direct dependence on the conditions of territory formation and balance of natural and anthropogenic factors in the territorial structure of nature management in Kharkiv. Therefore, it is advisable to use cartographic and descriptive information about the positional and dynamic structure of urban landscapes for the needs of environmental management. This is what this work is dedicated to.

The aim of the study is to create cartographic models of the positional-dynamic territorial structure of Kharkiv's landscape to ensure a balanced use of nature in environmental management.

Materials and methods of research. The positionaldynamic structure of the urban landscape was selected through compilation and analysis of cartographic works of landscape strips, tiers and districts.

The smallest indivisible unit of a positionaldynamic territorial structure of the landscape is the landscape strip, defined as the territory of the topical or choric level of $10^{2}-10^{8} \mathrm{~m}$. It is characterized by homogeneity of composition parameters, flow intensity and direction of horizontal flows in the landscape. Such processes are surface runoff, lateral geochemical migration and internal soil runoff.

These conditions are largely dependent on the following factors: morphometric parameters of the terrain, particle size distribution of the soil and their parent geological sediments. In the conditions of urban landscape, the establishment of the spatial structure and classification of urbogenic soils is a separate complex scientific task. For Kharkiv, it still remains unresolved. Therefore, the use of data on soil cover as one of the identifiers of landscape strips is considered a desirable but, in fact, unattainable requirement.

Identification and establishment of the territorial configuration of different types of landscape strips were based on the classical scheme of landscape locations' typology by water-geochemical regime, proposed by B. Polynov and supplemented by M. Glazovskaya (Glazovskaya, 2002), which includes 9 main types. A set of qualitative parameters is proposed, based on the characteristics of each type of landscape strips, by which they can be identified (Table 1).

The criterion for assigning the territory to a particular type of landscape strips is full compliance of its features with the whole combination of parameters of a certain type. In case when the areas with specifically combined groups of different parameters are established and regularly repeated, it is permissible to allocate intermediate "hybrid" types. 
Table 1. Criteria for selection types of landscape strips by water-geochemical regime

\begin{tabular}{|c|c|c|c|c|c|c|c|c|c|c|}
\hline $\begin{array}{l}\text { The main types of } \\
\text { landscape strips }\end{array}$ & 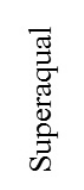 & $\frac{\bar{g}}{\frac{\pi}{2}}$ & 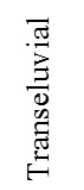 & $\frac{\vec{J}}{\frac{\pi}{\Delta}}$ & 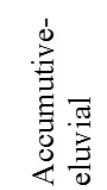 & $\frac{. \bar{J}}{\frac{\pi}{\Delta I}}$ & 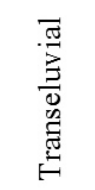 & 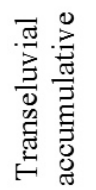 & 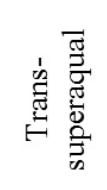 & 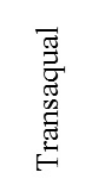 \\
\hline Index & Saq & $\mathrm{Aq}$ & Tr-El & El & Ac-El & $\mathrm{El}$ & Tr-El & Tr-Ac & Tr-Saq & Tr-Aq \\
\hline Prof & & & & & & & & & & \\
\hline Hypsometric level & $\mathrm{L}$ & $\mathrm{L}$ & $\mathrm{H}$ & $\mathrm{H}$ & $\mathrm{H}$ & $\mathrm{H}$ & $\mathrm{H}$ & $\mathrm{H}$ & $\mathrm{L}$ & $\mathrm{L}$ \\
\hline Surface slope & $\mathrm{F}$ & $\mathrm{F}$ & SSS & $\mathrm{F}$ & SS & $\mathrm{F}$ & SSS & SS & $\mathrm{F}$ & $\mathrm{F}$ \\
\hline Surface curvature & $\mathrm{F}$ & $\mathrm{CC}$ & $\mathrm{CS}$ & $\mathrm{F}$ & $\mathrm{CC}$ & $\mathrm{F}$ & $\mathrm{CS}$ & $\mathrm{CC}$ & $\mathrm{F}$ & $\mathrm{CC}$ \\
\hline Water table & $\mathrm{CO}$ & $\mathrm{CO}$ & $\mathrm{D}$ & $\mathrm{D}$ & $\mathrm{D}$ & $\mathrm{D}$ & $\mathrm{D}$ & $\mathrm{CO}$ & $\mathrm{CO}$ & $\mathrm{CO}$ \\
\hline Incoming substances & $\mathrm{A}, \mathrm{C}$ & $\mathrm{P}$ & B & $\mathrm{A}$ & A,B & A & B & $\mathrm{B}, \mathrm{C}$ & $\mathrm{A}, \mathrm{C}$ & $\mathrm{P}$ \\
\hline
\end{tabular}

Symbols: Hypsometric level: L - lowland, H - high; Surface steepness - F - flat or slightly inclined surface, SS - sloping surface, SSS - sloping or steeping surface; Surface curvature - F - flat surface, CC - concave surface, CS - convex surface; Water table - CO - close occurrence, D - deep occurrence; Source of substances introduction: A - mainly atmospheric, B - planar runoff, C - groundwater, P - surface water.

Technically, parameters were combined and territories' affiliation to certain types of landscape strips was determined by spatial analysis tools (in particular, reclassification and raster calculator) of initial data on morphometric relief parameters in ArcGIS.

Landscape strips, adjacent and similar in nature processes, interconnected by unidirectional substances horizontal flows, the intensity of which naturally decreases or increases, have been grouped into landscape tiers. Typically, within a positionaldynamic area tiers occupy a certain range of heights and mostly combine landscape strips of the same type.

Positional-dynamic zoning of the studied area was implemented by comparing the obtained cartographic work of landscapes and strips of tiers with data on the direction of surface runoff. The units of positionaldynamic zoning are actually districts and positionaldynamic formations.

A positional-dynamic region is distinguished as a union of landscape tiers, within which the process of scattering (divergence) of horizontal flows begins with the hypsometrically highest watershed line of the upper tier. It is limited to channel watercourses of $4^{\text {th }}$ order and above. The study consideres positionaldynamic formations of two types as positionally dynamic regions: type 1 - its boundaries are represented by 2 channels, type 2 - its boundaries are from two or more channels of different orders that can be tributaries.

Subdistricts are determined within the district, depending on the macroexposure of the surface slope. Macroexposure means the exposure of the total slope of the catenary from the watershed to the main line of runoff concentration within the area. It should be noted separately that subdistricts are not elementary positional-dynamic formations. They only unite polycatenar positional-dynamic formations composed of landscape strips of different types. Structure elements of positional-dynamic formations, delineated by watercourses of different orders (from 1 to 5 orders of magnitude), were distinguished to reflect the specifics of streams scattering from the lines of local watersheds as additional units.

Results and their analysis. Composition and territorial configuration of position-dynamic landscape strips of the urban landscape are established as a result of systematization and processing of geodata parametric features of the water-geochemical regime (Fig. 1). Totally, 13 types of landscape strips with individual features were identified, united into 5 groups according to the types of lateral substances migration. This was done due to the peculiarities of their positionality (common position relative to the frame lines of flow directions) and similarities of landscape morphology, flow and transfer intensity of substances (Table 2). The identified regime types and the nature of the spatial distribution of the corresponding types of landscape strips are briefly characterized.

Landscape strips of the eluvial regime occupy the upper positions of subhorizontal and very slightly sloping plains with a deep level of groundwater (more than $5 \mathrm{~m}$, different thickness). Predominant aerial supply of substances (with precipitation, dust, etc.) is common to this group. Introduction of the substance by surface runoff from adjacent landscape strips is 


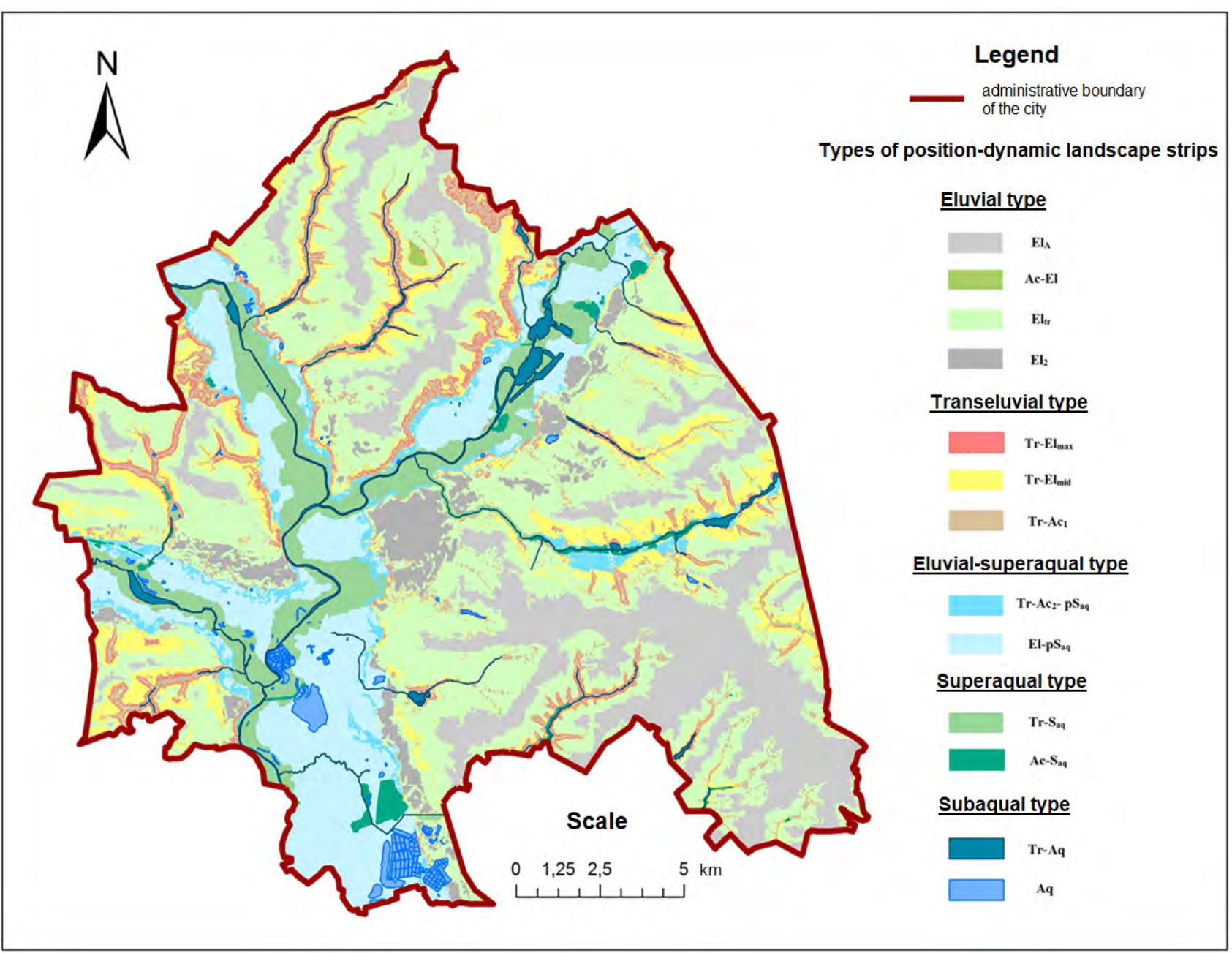

Fig. 1. Territorial structure of positional-dynamic strips of the urban landscape of Kharkiv

either absent or insignificant. In natural analogues of landscape strips of the eluvial regime substances are removed mainly in the vertical direction. Its inhibition is facilitated by the biological uptake of compounds and elements by plants and their retention in the biological cycle. However, in urban landscapes of eluvial regime, such a process of substances removal can be hindered by changes in the nature of the landscape: a significant proportion of waterproof surfaces (asphalting, high density of building foundations), presence of a canalized drainage system and reduction of areas occupied by plants. This leads to the formation of zonal landscapes different from the natural water regime.

Typical examples of "urban" transformations of the water-geochemical regime and their consequences of eluvial landscape strips within Kharkiv are:

formation of anthropogenic zones of deceleration and partial accumulation (road embankments, etc.) and increased transit of surface runoff (areas of artificial waterproof coverings, rainwater drainage) can lead to the formation of a wide range of variations in surface runoff formation conditions and geochemical migration of substances;

reduction of the vertical capacity of the leaching zone in the profile of urban eluvial landscape strips, which is potentially able to cause the accumulation of water-soluble compounds and relatively easily mobile elements in the upper soil horizons.

This group of landscape strips within the city of Kharkiv is represented by 4 types: autonomouseluvial $\left(\mathrm{El}_{\mathrm{A}}\right)$, accumulative-eluvial (Ac-El), eluvial secondary $\left(\mathrm{El}_{2}\right)$ and low-intensity transeluvial $\left(\mathrm{El}_{\mathrm{tr}}\right)$ within which lateral transport of substances has typical differences.

The most typical for this regime are autonomouseluvial landscape strips $\left(\mathrm{El}_{\triangle}\right)$, which occupy large areas within the city $(17.62 \%)$ and are confined to flat and slightly convex areas of watersheds and watershed plains with a surface slope of 0 to $1^{0}$ and deep groundwater occurrence. Two subtypes can be distinguished with a certain conditionality within this type of landscape strips:

- full autonomuous eluvial areas themselves, located on the most elevated positions, with undivided plains; 
Table 2. Types of positional-dynamic landscape strips in urban landscape of Kharkiv

\begin{tabular}{|c|c|c|c|}
\hline Index & Type of landscape strips & $\begin{array}{l}\text { Combination of parameters } \\
\text { of identificational features }\end{array}$ & $\begin{array}{c}\text { General characteristics of transfer } \\
\text { processes }\end{array}$ \\
\hline \multicolumn{4}{|c|}{ Eluvial regime } \\
\hline $\mathrm{El}_{\mathrm{A}}$ & Autonomous-eluvial & $\begin{array}{l}\text { Flat, subhorizontal }\left(0-1^{0}\right) \text { watershed plains, upper } \\
\text { altitude positions }\end{array}$ & $\begin{array}{l}\text { Removed substances with solid } \\
\text { and liquid runoff }\end{array}$ \\
\hline Ac-El & Accumulative-eluvial & Closed depressions, upper altitudes & Acculumation \\
\hline $\mathrm{El}_{\mathrm{tr}}$ & Transeluvial low intensive & $\begin{array}{l}\text { Straight and slightly convex declivous } \\
\text { slopes }\left(1-3^{0}\right)\end{array}$ & $\begin{array}{l}\text { Weakly intensive transit, partial } \\
\text { accumulation }\end{array}$ \\
\hline $\mathrm{El}_{2}$ & $\begin{array}{l}\text { Eluvial secondary of weak } \\
\text { transit }\end{array}$ & Flat, sub-horizontal plains of alluvial terraces $\left(0-1^{0}\right)$ & Weak transit, weak transit intensity \\
\hline \multicolumn{4}{|c|}{ Transeluvial regime } \\
\hline $\mathrm{Tr}-\mathrm{El}_{\max }$ & Transeluvial highly intense & Convex steep slopes $\left(15-40^{\circ}\right)$ & Highly intensive transit \\
\hline $\mathrm{Tr}-\mathrm{E} l_{\text {mid }}$ & $\begin{array}{l}\text { Transeluvial } \\
\text { moderately intense }\end{array}$ & Slightly convex slopes $\left(5-15^{0}\right)$ & Intensive transit \\
\hline $\mathrm{Tr}-\mathrm{Ac}_{1}$ & $\begin{array}{l}\text { Trans-accumulative slopes } \\
\text { of erosional forms }\end{array}$ & $\begin{array}{l}\text { Concave parts of steep slopes and open concave } \\
\text { bottoms of erosion forms }\end{array}$ & $\begin{array}{l}\text { Combined, accumulation and } \\
\text { transit }\end{array}$ \\
\hline \multicolumn{4}{|c|}{ Eluvial-superaqual regime } \\
\hline $\begin{array}{c}\mathrm{Tr}-\mathrm{Ac}_{2}- \\
\mathrm{pSaq}\end{array}$ & $\begin{array}{l}\text { Transaccumulative base of } \\
\text { slopes of valleys and cones } \\
\text { of erosion forms }\end{array}$ & $\begin{array}{l}\text { Sloping }\left(1-3^{0}\right) \text { footsteps of steep and sloping valley } \\
\text { slopes, in places - cones of ravine-depth systems } \\
\text { removal }\end{array}$ & $\begin{array}{l}\text { Combined, accumulation and } \\
\text { transit }\end{array}$ \\
\hline El-pSaq & Eluvial-superaqual & $\begin{array}{l}\text { Small hilly, shallow and leveled subhorizontal plains } \\
\text { of the second (pine) floodplain terrace }\end{array}$ & $\begin{array}{l}\text { Weakly intensive transit, accumu- } \\
\text { lation }\end{array}$ \\
\hline \multicolumn{4}{|c|}{ Superaqual regime } \\
\hline Tr-Saq & Transsuperaqual & Flat subhorizontal plains, the lowest & $\begin{array}{l}\text { Accumulation, weakly intensive } \\
\text { transit }\end{array}$ \\
\hline Ac-Saq & Accumulative-superaqual & Wetlands or floodplains & Accumulation \\
\hline \multicolumn{4}{|c|}{ Subaqual regime } \\
\hline $\operatorname{Tr}-\mathrm{Aq}$ & Transaqual & Watercourses with active channel runoff & Accumulation of channel transit \\
\hline $\mathrm{Aq}$ & Aqual & Lakes and drainless reservoirs & Accumulation \\
\hline
\end{tabular}

- eluvial areas of somewhat lesser degree of autonomy, located within the hypsometric ranges below the eluvial areas of complete autonomy. They are fragments of watershed plains "cut" by erosive landforms formed at the place of leveled ancient river terraces.

Accumulative-eluvial landscape strips (Ac-El) are represented by closed well-drained cavities in the relief, occupying elevated positions within the watershed plains. Substances introduced with atmospheric precipitation have the ability to accumulate, mobile water-soluble compounds usually have a tendency to radial removal. This type of landscape strips is not widespread within the city (less than $1 \%$ ) and covers an area of $0.28 \mathrm{~km}^{2}$. In total, 5 contours of this type have been installed, the largest of which is located within the catchment area of the Sarzhynka River with boundaries between Batumska street and Nova Pomerchanska street (Shevchenko district).
Eluvial secondary landscape strips $\left(\mathrm{El}_{2}\right)$ are well-drained plains or aligned subhorizontal $\left(0-1^{0}\right)$ flat plains of alluvial younger terraces. Their share in the positional and dynamic structure of the urban landscape of Kharkiv is $4.04 \%$.

The fact that this type of landscape strips is distinguished separately is explained by regime nature that differes from the autonomous-eluvial landscape strips. This uniqueness is due to the specificity of their location on the hypsometrically lower terraces of mostly Quaternary period, separated from the autonomous eluvial strips by landscape strips with more expressed lateral transit (transeluvial strips of varying intensity). Thus, the presence of this type of landscape strips in the structure of positional-dynamic areas indicates their stepped nature of the transverse profile of the tier that unites them.

This type of landscape strips has a specific nature of spatial distribution within the catchment areas 
of different rivers and certain positional variations in relation to landscape strips of other types. The territorial configuration of landscape strips of this type is diverse: it is represented by elongated liniments of different widths and spots of different sizes. The following hypsometric patterns can be noted in the nature of distribution:

- within the predominantly eastern part of the city, which corresponds to the left-bank parts of the catchment basins of the Kharkiv, Lopan and Uda rivers, successively flowing into each other, eluvial secondary landscape strips are mainly distributed on the sites of Pryluky-Udy terraces (typical altitude range 110-116 $\mathrm{m}$ ), individual strips are found within the older terraces.

- in the catchment area of the Uda river before the confluence with the Lopan river. This type of landscape strips is found mainly on the higher positions of the Kaidat-Tyasmin terrace (113-128 m) on both bank of the valley.

- within the valley of the Lopan river to the place where the Kharkiv river flows into it, the distribution of secondary eluvial landscape strips is limited and occurs in small spotted areas, corresponding to separate subhorizontal sections of the Lubny-Tiligul, single-Kaidat-Tyasmin terraces.

Thus, we can conclude that determining the specifics of the landscape strips regime of eluvialsecondary type is characterized by some variability. To understand possible effects of processes other than eluvial, clarification is needed for each landscape strip, depending on its location and proximity to other types of landscapes.

Transeluvial low-intensity landscape strips $\left(\mathrm{El}_{\mathrm{tr}}\right)$ are the most common in the positional-dynamic structure of the urban landscape of Kharkiv (33.54\%) and correspond to straight and slightly convex slopes $\left(1-3^{0}\right)$ of the watershed plains. With a certain degree of conventionality, they can be called an ecotonic type of landscape strips. Within these strips against the background of the predominant eluvial regime, the processes of weak lateral removal and accumulation of substances intensify. In cases when these landscape strips are under the active influence of removal from adjacent, located at higher positions of transeluvial moderate-intensity landscape strips, they significantly increase their role as areas of partial accumulation.

The group of transeluvial landscape strips incorporates slope locations with a combined supply of elements from the atmosphere and with a lateral inflow of substances from the eluvial landscape bands. Eluvial removal of substances is combined with the processes of transit and accumulation as to the profile.
In terms of composition and intensity of the prevailing processes, the landscape strips of the transeluvial regime are very heterogeneous. Thus, we can distinguish two types of transeluvial landscape strips that differ in genesis: slopes of erosive forms and valley river slopes. Based on the identified distinctive features determining the degree of intensity of lateral migrations and probable exogeodynamic processes, landscape strips of both types are divided into 3 types:

- transeluvial moderate-intensity strips $\left(\mathrm{Tr}-\mathrm{E} \mathrm{l}_{\text {mid }}\right)$ correspond to straight and convex sloping (50-150) in upper and middle parts of the slopes. They occupy $11.86 \%$ of the administrative territory of the city, being marked by the potential danger of linear and soil erosion;

- transeluvial high-intensity strips $\left(\mathrm{Tr}-\mathrm{E} \mathrm{l}_{\max }\right)$ are represented by convex steep sections of slopes (150400), occupying the upper and middle parts. These are areas of intensive transit of substances with a high risk of erosion and abrasive processes, soil erosion. They are distributed on $2.29 \%$ of the city;

- transaccumulative strips of lateral slopes of erosional forms $\left(\operatorname{Tr}-\mathrm{Ac}_{1}\right)$ with expressed processes of runoff products accumulation and significant dependence on transeluvial strips of moderate and high intensity. They are distributed in the lower concave parts of the slopes and open gently concave bottoms of catchment areas in the upper reaches of erosive forms (valley gorges and ravines), occupying 2.63\% of the territory.

The strips of the eluvial-superaqual regime found within the urban landscape are widespread in the territories that almost completely coincide with the contours of the territories of the Vitachiv-Bug (pine) terraces, occupying low-altitude positions with a shallow groundwater level (from 0 to $3 \mathrm{~m}$, thickness 15-18 m).

The strips of this type have a hybrid regime of lateral migration, which combines the features of eluvial, transaccumulative and transsuperaqual regimes. Its nature is determined by the cyclical mechanisms of their development.This defines this regime as post-superaqual, functioning in conditions when there is a significant connection with groundwater, which gradually loses its strength in the upper soil horizons and only in the wettest years acquires the signs of superaqual regime.

Eluvial-superaqual (El-pSaq) strips are the main type of landscape strips within this regime, occupying a large area. Their area corresponds to $13.15 \%$ of the city. They can be described as lowland leveled and small hilly subhorizontal surfaces with a low level of groundwater, which is mostly beyond the reach 
of the root layer of soils with a high capacity for infiltration and radial removal of surface runoff. One of the unfavorable processes that can intensify within them is the dispersal of sod sandy loam and sandy underdeveloped soils.

Sloping $\left(1-3^{\circ}\right)$ "plumes" at the foot of a valley are not so widely spread (2.67\%) in transaccumulative landscape strips ( $\mathrm{Tr}_{-} \mathrm{Ac}_{2}$-pSaq). In some places there are removal cones of ravine-gorge systems, in which removal products accumulate from transeluvial landscape strips in combination with probable periodic participation of groundwater in the processes of substances accumulation.

The superaqual regime of landscape strips is determined by close groundwater, the capillary border which reaches the root layer of the soil from one side, and incoming substances both from the atmosphere and from landscape strips of eluvial type. This creates favorable conditions for excess content relative to moving elements and water-soluble compounds.

Actual superaqual landscape strips associated with stagnant or low-flowing water of lakes and drainless reservoirs have not been mapped, as most of them are in the area of transsuperaqual-type landscapes. To determine the configuration of these strips for other landscape strips of this type it is necessary to do additional research of groundwater occurrence and the degree of humidity of the adjacent areas.

The trans-superaqual landscape strips ( $\mathrm{Tr}-$ Saq) distribution covering $9.00 \%$ of the city area, coincides with the contour of floodplain areas. They occupy mainly lowland areas of flat plains, in places complicated by the remnants of channel banks and shallow depressions, influenced by running water with active water exchange.

Accumulative-superaqual landscape strips (AcSaq) of wet or swampy hydromorphic areas with a nondiurnal surface of the capillary border of groundwater occupy $0.74 \%$ of the territory, a significant part of which is of anthropogenic origin.

The final link in the accumulation of substances within river basins are landscape strips of the subaquatic regime, which, in addition to transit, are characterized by the accumulation of solid alluvions in bottom sediments,transforming into sapropel organo-mineral deposits with high bitumen content.

Transaqual landscape strips (Tr-Aq) occupy $1.25 \%$ of the city's territory and represent the riverbeds of the Uda, Lopan, Kharkiv, Nemyshlya and other channel watercourses. Purely aqua landscape strips (Aq) are represented by numerous small in area (together occupying 1.13\%) wastewater bodies of mostly anthropogenic origin (Osnovyansk quarry, settling tanks and aeration tanks of Dykanka and Bezlyudovka sewage treatment plants, etc.). Integrating landscape strips with the same or similar in composition, direction and intensity regimes of lateral migration made it possible to distinguish 4 landscape tiers: eluvial (1), transeluvial (2), eluvialsuperaqual (3) and transsuperaqual (4) (Fig.2).

In these tiers of a positional-dynamic structure we notice the subordinative regularity of influence on each other that allows us to typologize them as follows:

- The autonomous tier combines landscape strips of the eluvial regime, which receive an influx of substances mainly from the atmosphere. Lateral movement of liquid runoff is inhibited by active radial removal, surface movement of solid runoff products is insignificant and is carried out slowly in the direction of sloping landscape strips by defluxation. Soil washout and erosion are unlikely.

- The tier of transit nature of landscape strips is represented by landscape strips of different types of regimes: both transeluvial and transsuperaqual and transaqual, etc., the location of which varies in a fairly wide range of heights. An integral feature of landscape strips within a given tier is their transit features, which determine the general trend for the movement of liquid runoff due to the significant slope of the relief surface within them. It is characterized by active processes of linear erosion, soil washout, in some places - accumulation of solid debris runoff, abrasion, landslides and suffusion.

- Tiers of accumulative nature occupy low-lying positions, as a result of what groundwater constantly or periodically participates in their functioning and there is an inflow from autonomous and transit tiers. Within these tiers, landscape strips of eluvialsuperaqual, transsuperaqual, and subaquatic regimes are widespread. Potential processes within these tiers are the dispersal of soils and loose sands (mainly for eluvial-superaqual), salinization of the soil layer (including soda) and contamination by inorganic and organic pollutants.

Positional-dynamic zoning of the urban landscape of Kharkiv city allows to reveal the territorial configuration and internal structure of 4 districts: Mzha-Uda, Uda-Lopan, Lopan-Kharkiv and Kharkiv-Velykobabchansk (Fig. 3).

Mzha-Uda position-dynamic district is located in the north-western part of the city and is the smallest in terms of territorial distribution $(5.5 \%$ of the total area). The Uda riverbed is the boundary of the district on the territory of the city. The district consists of 2 


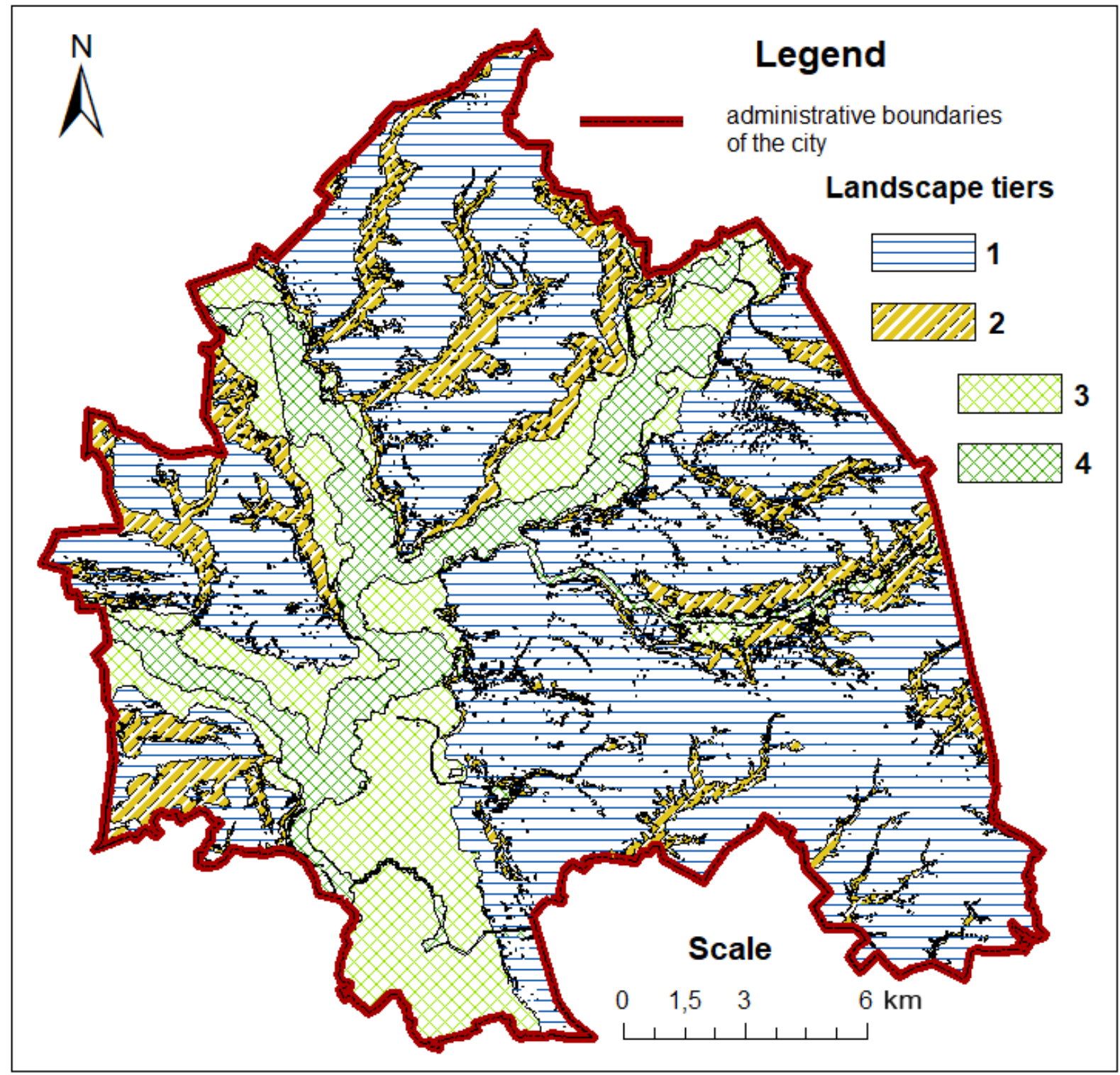

Fig. 2. Tiers of the positional-dynamic structure of the urban landscape of Kharkiv

(1 - eluvial, 2 - transeluvial, 3 - eluvial-superaqual,4 - transsuperaqual)

subdistricts of northern and eastern macroexposure with almost equal areas within the city.

The most common tiers of the district are eluvial and transeluvial (Fig. 4), accounting for $36 \%$ and $34 \%$, respectively. Landscape strips of the eluvialsuperaqual tier occupy $19 \%$, superaqual $-11 \%$.

Uda-Lopan positional-dynamic area covers the western part of the city. It occupies $14.4 \%$ of the city area. The boundaries of the district are the Uda and Lopan riverbeds, their shape resembles a slice. The area in the meridional direction is divided into subdistricts of southern and northeastern macroexposure with a close area.

Within the district, the largest areas are occupied by eluvial landscape strips (40\%). Transeluvial, eluvial-superaqual and superaqual tiers occupy $19.8 \%, 21.6 \%$ and $18.38 \%$, respectively.
Lopan-Kharkiv positional-dynamic district is located in the northern part of the city,covering $22.5 \%$ of its territory. The area is bounded by the riverbeds of the Lopan and Kharkiv rivers, merging at an acute angle, determining its wedge-shaped shape. Two thirds of the district belongs to the sub-region of the southwestern macroexposure. The rest of the district belongs to the subregion of the southern macroexposure with a high degree of erosional dismemberment, most of the erosional forms of which "open" in the southeastern direction. More than a half of the district area belongs to the eluvial tier (56.5\%), about a quarter is occupied by the transeluvial tier $(25.4 \%)$, the rest of the territory belongs to the eluvial-superaqual $(11.3 \%)$ and superaqual tiers $(6.8 \%)$.

Kharkiv-Velykobabchansk position-dynamic district is the largest district $(57.6 \%)$, located in 


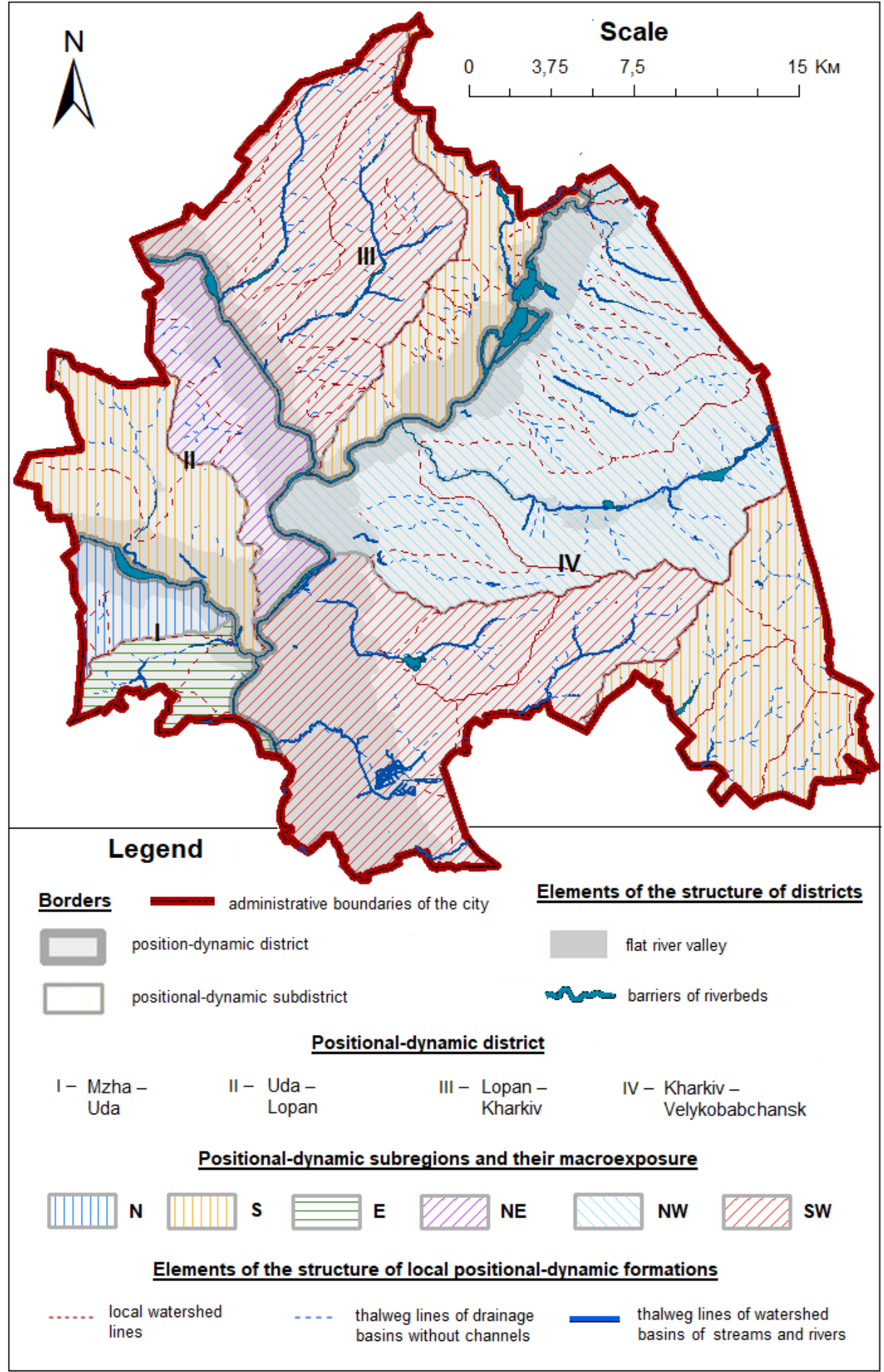

Fig. 3. Position-dynamic districts of the urban landscape of Kharkiv city

the north-eastern and southern part of the city. In general, this area has a shape close to the ellipsoid, and its boundaries are the Kharkiv River, Lopan River, Uda River, Siversky Donets River and Velyka Babka River (the last two are outside the city). There are 3 subregions: of north-western macroexposure, oriented mainly to the Kharkiv riverbed; southwestern macroexposure - to the fragments of the Lopan and Uda riverbeds, which protrude beyond the boundaries; and the southern macroexposure, general orientation of which is directed towards the Uda riverbed in the lower course.

The district is characterized by the dominance of the eluvial tier $(60.9 \%)$, a significant share in the structure is occupied by the eluvial-superaqual tier $(18.47 \%)$, the share of transeluvial and transsuperaqual tiers is $12.45 \%$ and $8.11 \%$, respectively. 


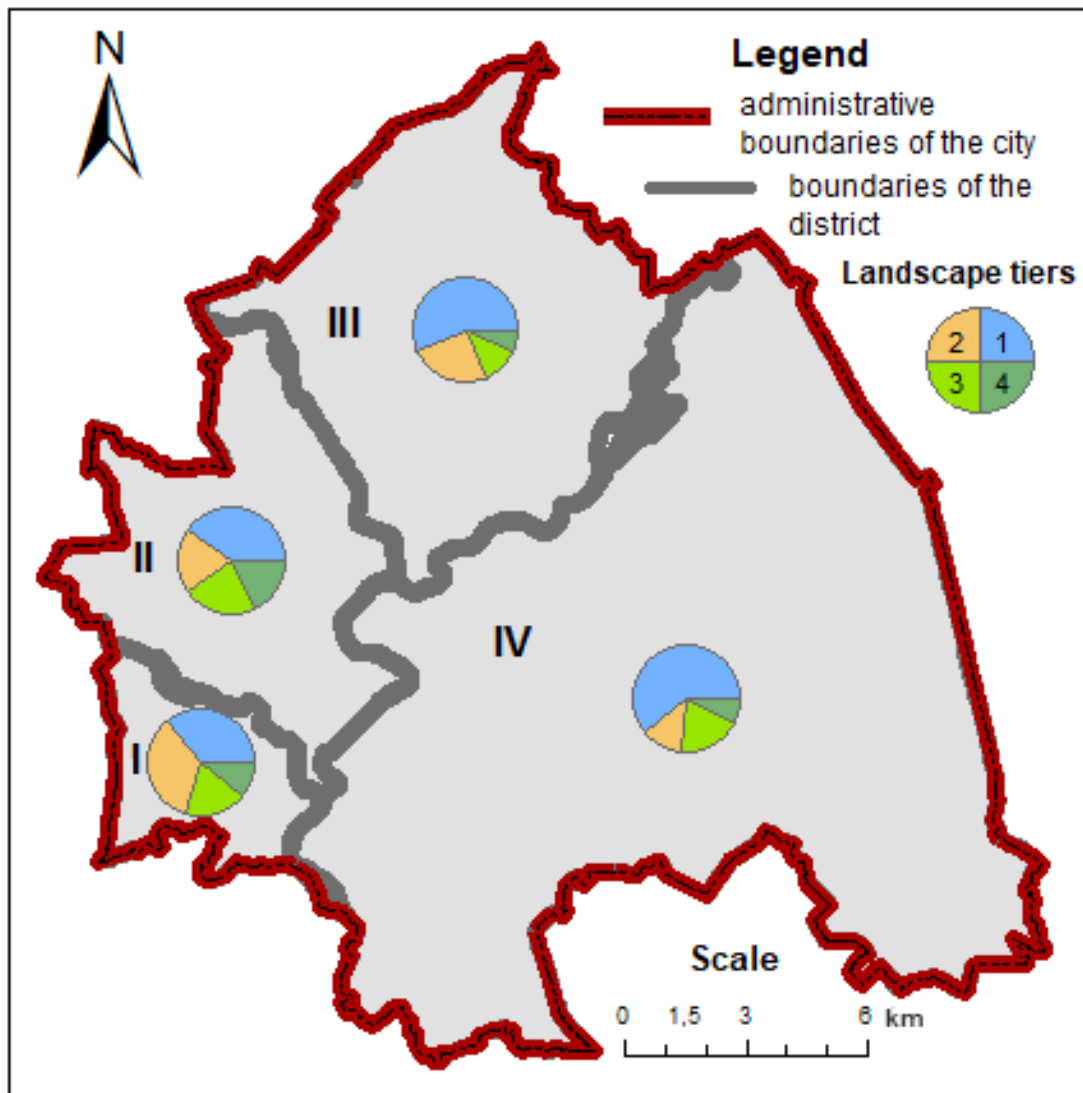

Fig. 4. Distribution of tiers within the positional and dynamic districts of the urban landscape of Kharkiv city (1 - eluvial, 2 - transeluvial, 3 - eluvial-superaqual,4 - transsuperaqual)

\section{Conclusions}

1. When implementing the first stage of landscape-ecological planning - inventory in the city, it is necessary to analyze the ratio of natural and anthropogenic factors in the formation of its territory, which will provide a basis for developing environmental management measures for sustainable nature management.

2. The positional-dynamic structure of urban landscape can be selected by compiling and analyzing cartographic works of landscape strips, tiers and areas, using spatial analysis tools (including reclassification and raster calculator) of initial data on morphometric parameters of relief in ArcGIS.

3. The composition and territorial configuration of position-dynamic landscape strips of the urban landscape have been established as a result of systematization and processing of geodata parametric features of the water-geochemical regime.

4. 13 types of landscape strips with individual features are identified in the territory of Kharkiv city. They are united into 5 groups according to the types of lateral migration of substances due to the peculiarities of their positionality (common position in relation to frame lines of changing flow directions) and similarity factors of relief morphology, the nature of the flow and the intensity of substances transfer.

5. Cartographic models of the positional-dynamic territorial structure of Kharkiv city, developed during the implementation of the inventory stage of landscape-ecological planning, make it possible to choose the directions of balanced nature management in environmental management of a particular area.

\section{References}

Glazovskaya, M. A., 2002. Geohimicheskie osnovy tipologii i metodiki issledovanij prirodnyh landshaftov [Geochemical foundations of typology and methods of research of natural landscapes] (2rd ed.). Smolensk: Oikumena (in Russian).

Hrodzynskyi, M. D., 2005. Piznannya landshaftu: mistse i prostir [Cognition of the landscape: location and space]. Vol 2. Kyyiv Vydav.- polihraf. tsentr «Kyyivs'kyy universytet» (in Ukrainian).

Hrodzynskyi, M. D., 2014. Landshaftna ekolohiya [Landscape ecology]. Kyyiv.: Znannya (in Ukrainian).

Hrodzynskyi, M. D., Shyshchenko, P. H., 1993. Landshaftno-jekologicheskij analiz $\mathrm{v}$ meliorativnom prirodopol'zovanii [Landscape-ecological analy- 
sis in melioration land use]. Kyyiv: Lybid' (in Russian).

Karpets, K. M., 2015. Landshaftno-heokhimichne modelyuvannya na pidstavi heoinformatsiynykh modeley vodozboriv [Landscape-geochemical simulation on the basis of information models catchment]. Visnyk of V. N. Karazin Kharkiv National University. Ser. Ecology. 13, 44-48 (in Ukrainian). https://periodicals.karazin.ua/ecology/article/ view/5534

Klieshch, A. A., Maksymenko, N. V., Ponomarenko, P. R., 2017. Terytorial'na struktura pryrodokorystuvannya mista Kharkiv [Territorial structure of the land use of Kharkiv city]. Lyudyna ta dovkillya. Problemy neoekolohiyi. №1-2. 23-34 (in Ukranian). DOI: 10.26565/1992-4224-2018-30-03

Kostrikov, S. V., Maksymenko, N. V., 2010. Heoinformatsiinyi pidkhid do vyznachennia fraktalnykh kharakterystyk pryrodno-antropohennoho dovkillia. [Geoinformation approach towards the environmental fractal properties]. Physical Geography and Geomorphology 4(61). 20-35 (in Ukrainian).

Kostrikov, S. V., Chervanyov, I. G., 2010. Doslidzhennia samoorhanizatsii fliuvialnoho reliefu na zasadakh synerhetychnoi paradyhmy suchasnoho pryrodoznavstva [Research of the fluvial landform self-organization phenomenon on the basic of the modern natural science synergetic paradigm]. Kharkiv : V. N. Karazin Kharkiv National University (in Ukrainian).

Maksymenko, N. V., 2018. Landshaftno-ekolohichne planuvannya: teoriya i praktyka [Landscape-ecological planning: theory and practice]. Kharkiv: V. N. Karazin Kharkiv National University (in Ukrainian).

Maksymenko, N. V., Klieshch, A. A., 2017. Napryamky optymizatsiyi pryrodokorystuvannya V invayronmental'nomu menedzhmenti terytoriy lokal'noho rivnya orhanizatsiyi dovkillya [Directions for optimization of natural resource use in environmental management for local areas]. Dniprop. Univer. bulletin, Geology, geography., 25(2), 81-88 (in Ukrainian). doi: $10.15421 / 111722$.

Shvebs, H. Y., Shyshchenko, P. H., et al., 1990. Metodicheskie ukazanija po landshaftnym issledovanijam dlja sel'skohozjajstvennyh celej [Guidelines for landscape research for agricultural purposes]. Moskva: Izd-vo VASHNIL (in Russian).

Udovychenko, V. V. ,2016a. Landshaftna pozytsiynodynamichna struktura terytoriyi Livoberezhnoyi Ukrayiny: rehional'nyy aspekt [Landscape positional-dynamic structure of the Left bank the Dnipro river of Ukraine territory: regional aspect]. Visnyk of V. N. Karazin Kharkiv National University. Ser. Ecology. 14, 33-40 (in Ukrainian). https:// periodicals.karazin.ua/ecology/article/view/6338

Udovychenko, V. V., 2016b. Lokal'na spetsyfika pozytsiyno-dynamichnoyi landshaftnoyi struktury lisostepovykh kompleksiv terytoriyi Livoberezhnoyi Ukrayiny [The positional-dynamic landscape structure of forest-steppe complexes of the LeftBank the Dnipro river of Ukraine territory local specificity]. Physical Geography and Geomorphology. 2(82), 58-66 (in Ukrainian). https://doi. org/10.17721/phgg.2016.2.08

Vlasova, A., 2013. Doslidzhennya landshaftnykh terytorial'nykh struktur baseynovykh terytoriy (na prykladi baseyniv richok systemy Salhyra) [Analysis of landscape territorial structures of basin areas (the basins of Salgir river case study)]. Physical Geography and Geomorphology. 2(70), 10-17 (in Ukrainian). 